Arabic; the teaching of Arabic up to elementary school standard; local affairs: Protectorate history, soil erosion and protection of trees, the aims and work of various Government departments; first aid, including attendance at the local dispensary and the out-patients department of the nearest hospital.

After this first group of instructors have been working in the field for six months, they will be recalled and invited to report on the results of their work. If the scheme has been well received, it is hoped to train a larger number of instructors and not only to raise the standard of Arabic teaching but to add instruction on hygiene, veterinary work, \&c.

\title{
Duquesne University (Pittsburgh, U.S.A.). Institute of African Affairs
}

AN Institute of African Affairs is being established at Duquesne University under the direction of the Rev. F. M. Philben, C.S.Sp., who has served for six years as a missionary in Africa. It is hoped to start some courses of African study in 1957 and to develop a full graduate programme within three or four years. The purpose of the new Institute is to stimulate serious thinking on African affairs and to provide trained personnel for government and industry. The Institute hopes eventually to offer graduate and some undergraduate courses, to sponsor African conferences, conduct student and teacher exchanges between Africa and America, and provide speakers expert in African subjects.

\section{Professor Diedrich Westermann}

Funeral ceremonies in memory of Diedrich Westermann were held in a number of places among the Ewe people on 16 September 1956. The Secretary of the Synod of the Evangelical Church of Togo, reporting the ceremony to the Norddeutsche Mission in Bremen (which had first sent Westermann as a missionary to Togoland), wrote: 'All the Christians, Protestants as well as Catholics, and even pagans, sent their greetings to the family of Westermann-the beloved and tireless benefactor of native culture and Ewe literature. The work he did for them will be cherished in the memory of the Ewe people from generation to generation for centuries to come' (E. Dammann, in Le Monde non chrtien, Dec. 1956).

\section{A French Social Centre in Lagos}

THE French Social Centre in Lagos is primarily a club for French subjects from Dahomey, Togo, Niger, Chad, Cameroons, and other territories of French Africa, who are resident in Nigeria. Classes in French are held twice a week for adults and children, the average attendance at these being about sixty. French newspapers and magazines are available to all members. Besides its social activities the Centre provides a temporary lodging for French subjects who are seeking to be repatriated. Rooms are available where persons without other resources in Lagos can stay till funds for their return journey have been sent to the French Consul from the territory to which they belong. Among those who, for one reason or another, are stranded in Lagos without money, a considerable number are herdsmen who have travelled on foot from Niger or Chad to bring their cattle to the Nigerian markets.

\section{Religion and Social Change in Modern East Africa}

A seminar held at Makerere College in the spring term of 1956 discussed a number of problems arising from the impact of Christianity on East African peoples, missionary methods and teaching, the behaviour and outlook of African Christians in the past and today, and their relations with non-Christians. Revivalist movements and their relations with the organized churches were also discussed. Those participating in the seminar were students and lecturers of Makerere College and a report of the seminar has been circulated privately; it is understood, however, that one of the papers read will be published shortly. 